\title{
Mathematical Modelling for Predicting the Performance of Photovoltaic Module
}

\author{
Siti Nurashiken Md Sabudin ${ }^{1^{*}}$, Norazaliza Mohd Jamil ${ }^{2}$ and Saifful Kamaluddin bin Muzakir@Lokman ${ }^{2}$ \\ ${ }^{1}$ Bahagian Tajaan Pendidikan., Kementerian Pendidikan Malaysia Aras 1, Blok 2251, Jalan \\ Usahawan 1, 63000 Cyberjaya, Selangor Darul Ehsan \\ ${ }^{2}$ Faculty of Industrial Sciences \& Technology, Universiti Malaysia Pahang, Lebuhraya Tun Razak, \\ 26300 Gambang Kuantan, Pahang Darul Makmur
}

The demand for photovoltaic (PV) system is growing rapidly driven by technological development and awareness of green environment. A photovoltaic system converts the energy of light into electricity without emission of harmful by-product. A complete PV system consists of a solar panel (which combination of few solar cells), Pulse Width Modular (PWM) and a battery. Eight photovoltaic parameters are used to characterized the quality and efficiency of a PV module i.e (i) short circuit current $\left(I_{S C}\right)$, (ii) open circuit voltage ( $\left.V_{O C}\right)$, (iii) Theoretical Power $\left(P_{T}\right)$, (iv) maximum power $\left(P_{M A X}\right)$, (v) voltage at PMAX ( $\left.V_{M P P}\right)$, (vi) current at PMAX ( $\left.I_{M P P}\right)$, (vii) fill factor $(F F)$ and (viii) efficiency ( $\eta$ ). The PV parameters of laboratory scale solar cell could be determined based on current-voltage $(I-V)$ and powervoltage $(P-V)$ curves which could be plotted using a combination of solar simulator and a potentiostat instruments. Two additional PV parameters i.e (i) reverse saturation current of diode ( $I_{R C}$ ) and (ii) photocurrent $\left(I_{P V}\right)$ have been studied intensively as input of mathematical models to simulate and determine the quality and efficiency of solar cells. However, reproduceable results and robust mathematical models are yet to be established. A mathematical model employing the $I_{R C}, I_{P V}$ and diode ideality factor $(a)$ - which received lack of focus by previous researchers; is proposed. We have validated the mathematical model by comparing the calculation $I-V$ and $P-V$ curves results with the specifications established by the manufacturer. We have conducted three studies based on different specification of silicon based solar module i.e (i) $300 \mathrm{~W}$, (ii) $265 \mathrm{~W}$ and (iii) $250 \mathrm{~W}$ to obtain temperature distributions and average solar irradiance at selected locations. Through a comparative analysis, the theoretical calculation results and the manufacturers' specifications are in good agreement.

Keywords: mathematical modelling, photovoltaic, performance of PV, temperature, solar irradiance 


\section{INTRODUCTION}

Solar energy is sustainable and totally inexhaustible, unlike the current fossil fuels source which is finite. It does not emit any greenhouse gases when producing electricity and known a non-polluting source of energy. The electricity that is produced can supply the energy consumption without pollutes the Mother Nature. The fossil fuel is indispensable in producing electricity due to cheap and reliable sources of energy and the technology used is well developed. However, fossil fuels release carbon dioxide when they burn while producing electricity, which contributed to global warming seriously. Besides, fossil fuels are non-renewable energy sources and not replenished naturally. Nowadays, humanity has declared its readiness to accelerate the transition from fossil fuels to renewable energy.

Then, renewable energy sources have begun to be prioritized in the generation of electricity. Solar energy, wind energy and geothermal are some examples of renewable energy used in production of electricity. In Malaysia, solar energy would be the best choice for electricity generation due to geographical factor which is characterized by near the equator showed the most efficient in their collection of solar irradiances (Rosario, 2014). The photovoltaic system functions as a sunlight converter to change it to electricity directly. Photovoltaic modules consist of cells that are assembled in series and / or parallel to form modules, and modules wired together to form a panel. The numbers of solar irradiance emitted by the sun influenced the output power of photovoltaic module and is proportionally. A decade years ago, the studies showed the plausible factors influenced the performance of PV system are temperature and solar irradiance but with minimal used in the mathematical modelling (Gow \& Manning, 1999; Zhou et al., 2007; Tsai et al., 2008; Villalva et al., 2009). Those studies agreed with the same opinion that the environmental parameters and manufacturers' specification significantly affected in producing the maximum power from PV systems. Afterwards, the studies necessary to consider the effects of environmental factors influenced to each parameter. Zhou et al. (200u) highlighted their findings by calculating three constants in predicting the performance of PV system by considering the temperature as the main factors. While Brano et al. (2010) mentioned the series and shunt resistances are affected by the solar irradiance further proving that the environmental factor influenced the manufacturers' hardware specification. Xu \& Wang (2017) proved that when the manufacturers' specifications and environmental factors are taken into account, the mathematical modelling can be used for other PV hardware models. It is shown the model stable and sustainable.

Most of PV systems are developed based on circuitry methods and limited number of research has been reporting are focusing on development of numerical methods (KoohiKamali et al., 2016; Suthar et al., 2013). Various studies have been done before to enhance PV system e.g; (i) development of PV system, (ii) implementation the system in a small or large scale (iii) acceptance of the system in the community. Due to optimizing the cost, mathematical modelling may help to improve the system and the effects of different components in making prediction of the performance behaviours. In the mathematical modelling the manufacturers' specifications parameters can be change according to the PV hardware model. While the environmental factors will be designed in developing the mathematical model to predict the performance of PV model accurately. Thus, different PV hardware models with various temperature and solar irradiance can be simulated in this mathematical model

In this study, we propose a mathematical modelling by considering plausible factors to predict the performance of PV modules. To demonstrate its usefulness and superiority, the proposed mathematical modelling ran for various model of PV Module and compared experimental data from manufacturer. Both test results and comparison results demonstrate that the performance and superior practical utility.

\begin{tabular}{|c|c|c|c|}
\hline \multicolumn{4}{|c|}{ Nomenclature } \\
\hline$I_{O}$ & $\begin{array}{l}\text { output current of PV } \\
\text { module }\end{array}$ & $K_{i}$ & $\begin{array}{l}\text { short-circuit } \\
\text { current/temperat } \\
\text { ure coefficient }\end{array}$ \\
\hline$V$ & $\begin{array}{l}\text { output voltage of } \\
\text { PV module }\end{array}$ & $G$ & $\begin{array}{l}\text { actual solar } \\
\text { irradiation }\end{array}$ \\
\hline$I_{P V}$ & photocurrent & $G_{n}$ & $\begin{array}{l}\text { solar irradiation } \\
\text { at STC }\end{array}$ \\
\hline & & & $\left(1000 \mathrm{~W} / \mathrm{m}^{2}\right)$ \\
\hline$I_{R C}$ & $\begin{array}{l}\text { reverse saturation } \\
\text { current of diode }\end{array}$ & $N_{S}$ & $\begin{array}{l}\text { the number of } \\
\text { cells connected } \\
\text { in series }\end{array}$ \\
\hline
\end{tabular}




\begin{tabular}{|c|c|c|c|}
\hline$V_{T}$ & diode voltage & $V_{O C}$ & $\begin{array}{l}\text { open circuit } \\
\text { voltage }\end{array}$ \\
\hline$T$ & ambient temperature & $I_{S C}$ & $\begin{array}{l}\text { short circuit } \\
\text { current }\end{array}$ \\
\hline$T_{n}$ & $\begin{array}{l}\text { temperature at STC } \\
25^{\circ} \mathrm{C}\end{array}$ & $I_{M P P}$ & $\begin{array}{l}\text { current at } \\
\text { maximum power }\end{array}$ \\
\hline$q$ & $\begin{array}{l}\text { electron charge } \\
\left(1.6021 \times 10^{-19} \mathrm{C}\right)\end{array}$ & $V_{M P P}$ & $\begin{array}{l}\text { voltage at } \\
\text { maximum power }\end{array}$ \\
\hline$k$ & $\begin{array}{l}\text { Boltzmann constant } \\
\left(1.3807 \times 10^{-23} \mathrm{~J} / \mathrm{K}\right)\end{array}$ & $P_{M A X}$ & maximum power \\
\hline \multirow[t]{2}{*}{$\Delta T$} & $\begin{array}{l}\text { the difference } \\
\text { between ambient } \\
\text { temperature and }\end{array}$ & $I_{S C n}$ & $\begin{array}{l}\text { short circuit } \\
\text { current given by } \\
\text { manufacturer }\end{array}$ \\
\hline & nominal temperature & $R_{S H}$ & Shunt resistance \\
\hline$a$ & diode ideality factor & $E_{g n}$ & Band gap at $T_{n}$ \\
\hline$R_{S}$ & Series resistance & $E_{g}$ & Band gap \\
\hline
\end{tabular}

II. MATHEMATICAL MODELLING

\section{A. The ideal model of PV module using single diode model}

Phang et al. (1984) derived an analytical expression to extract the parameter of solar cells by using single diode model. This model incorporated between numerical methods with circuitry-based method. Figure 1 shows the equivalent circuit of photovoltaic cell consists of a single diode which connected in parallel with a photocurrent source. The ideal output current $\left(I_{O}\right)$ for Figure 1 written as $I_{o}=I_{P V}-I_{D}-I_{S H}$. Most of researcher selected the single diode model (KoohiKamali et al., 2016) for development of PV cells (KoohiKamali et al., 2016). This model is simply understood and effective model for simulate the behaviour of PV module by taking into account the impacts of selected factors.

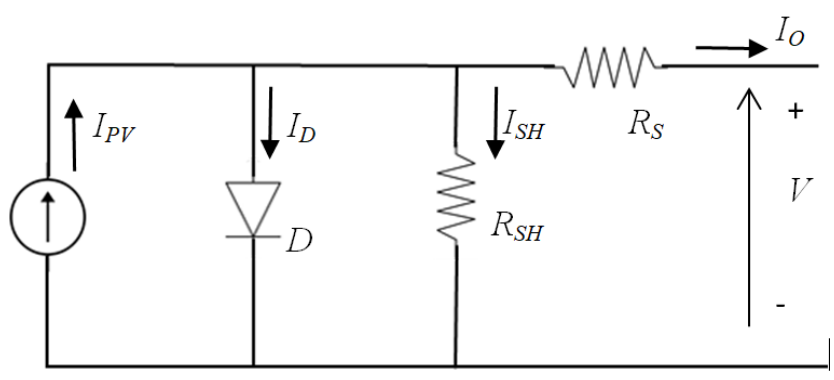

Figure 1. Ideal single diode model.
The output current $\left(I_{o}\right)$ can be formulated as ;

$$
I_{O}=I_{P V}-I_{R C}\left[\exp \left(\frac{V+I R_{S}}{a V_{T}}\right)-1\right]-\frac{V+I R_{S}}{R_{S H}}
$$

where $\quad V_{T}=\frac{k T}{q} \quad, \quad I_{P V}=\left(I_{S C}+K_{I} \Delta T\right) \frac{G}{G_{n}}$,

$$
I_{R C}=I_{R C n}\left(\frac{T_{n}}{T}\right)^{3} \exp \left[\frac{q E_{g}}{a k}\left(\frac{1}{T_{n}}-\frac{1}{T}\right)\right]
$$
and

$E_{g}=1.16-7.02 \times 10^{-4}\left(\frac{T^{2}}{T-1108}\right)$

Some

researchers made assumption on the value of $a$. For example $a=4$ (Shukla et al., 2007), $a=1$ (Mares et al., 2015) and $1<a<2$ (Chin et al., 2015). $T_{n}$ is nominal temperature at standard temperature condition (STC) given by manufacturer datasheet.

Tian et al. (2012) presented derivation of the modified equation 1 by expanding for PV module. Development of the model was based on a five-parameter model. The new output current $\left(I_{O M}\right)$ becomes;

$I_{O M}=I_{P V}-I_{R C}\left[\exp \left(\frac{\left(V+N_{S} I R_{S}\right)}{N_{S} a V_{T}}\right)-1\right]-\frac{V+N_{S} I R_{S}}{N_{S} R_{S H}}$

Thus, the single diode model is the simple approach and can be applied in majority of solar cells. It offers simplicity and accuracy (Humada et al., 2016;Rahman et al., 2014;Suthar et al., 2013).

\section{B. $\quad$ The Current, Voltage and Power Characteristics Curve}

Current-Voltage $(I-V)$ and Power-Voltage $(P-V)$ characteristic curves used to determine and understand the basic parameters of a component or device. The curve (Figure 2) for PV module describes the capability of energy conversion at the existing conditions. Conceptually, the curve represents the combinations of current, voltage and power at which the string could be operated or 'loaded', if the solar irradiance and cell temperature could be held constant.

The curves of $I-V$ and $P-V$ characteristics for PV cell, is determining the device's output performance and solar 
efficiency. $I_{S C}$ is the maximum current that the cell can provide and it occurs when the cells is short circuited. $V_{O C}$ is the maximum voltage that exists between the cells' terminals and is obtained when there is no load connected across them. $V_{M P P}$ and $I_{M P P}$ are being produced by the cell. It is called as $P_{M A X}$ is product of $V_{M P P}$ and $I_{M P P}$. Whereas, $V_{O C}, I_{S C}$, $V_{M P P}, I_{M P P}$ and $P_{M A X}$ are given by manufacturer. Figure 2 described the plotting point of $V_{O C}, I_{S C}, V_{M P P}, I_{M P P}$ and $P_{\text {MAX }}$

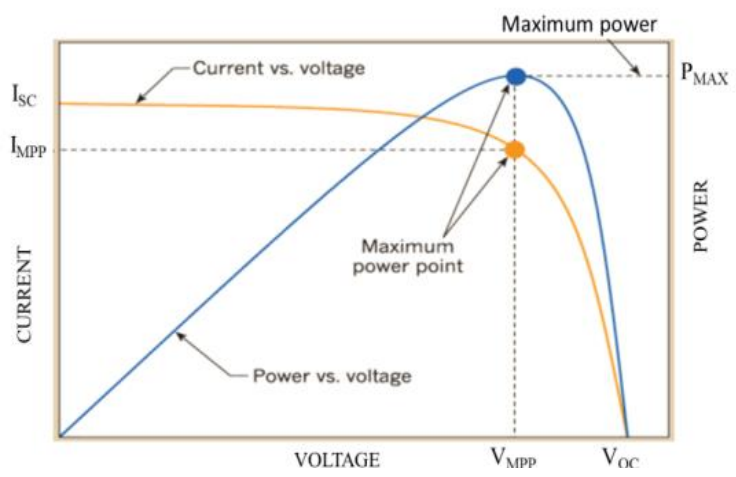

Figure 2. A typical current, voltage and power curve.

\section{The Proposed Mathematical Model}

The focus will be on a single diode model for PV cell. In practice, PV cells are connected in series into PV module and these PV modules are connected to form PV arrays for generating more electricity depending on the load's need. The performances of PV modules affect PV arrays too.

The mathematical model is important because it has the ability to predict the PV cells behaviour and performance by considering the plausible factors. In this study, the factors affecting the performance of PV module are $G$ and $T$ (Hu \& Yao, 2016;Vergura, 2016; Chander et al., 2015;Shukla et al., 2007). These factors will influencing $I_{P V}, I_{R C}, R_{S}, R_{S H}$ and $a$. The others factor should be considered is fitted parameter given by manufacturer.

An accurate estimation of performance for PV module is the main goal by minimal in making assumption. The previous study agreed that $I_{R C}$ as represent the characteristics of a component that caused the accuracy of $I$. Thus photocurrent
$\left(I_{P V}\right)$ is an electric current produced by a photoelectric effect but it is not counted as output current due to leakage that representing by diode and resistances showed in Figure 1, measuring of combination between environmental factors and specification of photovoltaic module (Rahman et al., 2014). The proposed model for $I_{P V}$ is formulated as given;

$$
I_{P V}=\left[I_{S C}\left(\frac{G}{G_{n}}\right)\left(1+K_{i}\left(T-T_{n}\right)\right)\right]
$$

The leakage factor should be considered in the system is representing by the current through diode and resistances. The estimation of $I_{R C}$ has be considered with environmental and working condition for having more accurate solution. The proposed $I_{R C}$ is formulated as Equation (4). While, mathematical model for $a$ developed by considered band gap and temperature as given as in Equation (5).

$$
I_{R C}=\left[\frac{I_{S C}}{G_{n}}\left(\frac{G_{n}}{G}\right)^{3} \exp \left(\frac{E_{g n}}{K_{i} T_{n}}-\frac{E_{g}}{K_{i} T}\right)\right]
$$

$$
a=\frac{E_{g}-q V_{o c}}{k T\left(\operatorname{In} \frac{I_{M P P}}{I_{S C}}\right)}
$$

In proposed $I_{R C}$, band gap $\left(E_{g}\right)$, solar irradiance, (G) and temperature (T) were implemented to represent main factor that affected to accuracy.

Substitute Equation (3) and (4) in (1), then:

$$
\begin{aligned}
I_{O} & =\left[I_{S C}\left(\frac{G}{G_{n}}\right)\left(1+K_{i}\left(T-T_{n}\right)\right)\right] \\
- & \left(\left[\frac{I_{S C}}{G_{n}}\left(\frac{G_{n}}{G}\right)^{3} \exp \left(\frac{E_{g n}}{K_{i} T_{n}}-\frac{E_{g}}{K_{i} T}\right)\right]\right) \\
& {\left[\begin{array}{l}
\left.\exp \left(\frac{V+N_{S} I R_{S}}{N_{S} a}\right)-1\right] \\
k T / q)
\end{array}\right] } \\
- & \frac{V+N_{S} I R_{S}}{N_{S} R_{S H}}
\end{aligned}
$$

Humada et al. (2016) suggested that an appropriate equation for resistance must be developed and the factors 
would be selected carefully. The resistances represented the leakage that happened in the PV cells systems and must be taken into highly consideration (Vergura, 2016). Previous research set the value of the resistance either for the whole repetitive iterative or as starting value and it was not discussed or proofed in the written. The proposed model for resistance is improving from Rahman et.al (2014). The proposed model for $R_{S H}$ becomes as;

$R_{S H}=\frac{\left(N_{S} I_{S C} R_{S}-V_{O C}\right)\left(e^{q A / B}\right) q+B\left(e^{C}-1\right)}{\left(\left[\left(N_{S}{ }^{2} I_{M P P} a k T\right)\left(e^{C}-1\right)\right] / D\right)-\left[\left(e^{q A / B}\right)\left(q N_{S} I_{S C}\right)\right]}$

with $A=V_{M P P}+N_{S} I_{M P P} R_{S} \quad, \quad B=a k T N_{S}$

$C=q V_{O C} / a k T N_{S}$ and $D=V_{M P P}-N_{S} I_{M P P} R_{S}$.

Thus, the proposed model for $R_{S}$ given as;

$$
R_{S}=\frac{a k T}{q I_{M P P}} \ln \left[e^{C}-\frac{I_{M P P}}{I_{S C}}\left(e^{C}-1\right)\right]-\frac{V_{M P P}}{N_{S} I_{M P P}}
$$

The effectiveness of the proposed mathematical model proofed with power converters by $P=V I_{O}$. Therefore, the simulation ran by using repetitive iterative technique for different operating levels.

The next task in this study is set for our MATLAB programming to calculate the measured and predicted current productions and efficiencies for different PV modules. The script file is developed for programming in MATLAB and the result will discuss in next section.

Simulation program is developed with considering singlediode PV cell mathematical model without neglecting series and shunt resistances. All the specific values of the input and climatic parameters are taken account at Kuantan (i.e: ambient temperature and solar irradiance distribution. Simulation program tested on matlab/simulink for JA Solar JAM6 72/300-320 Monocrystalline Silicon Module.

\section{RESULTS AND DISCUSSIONS}

The model's specifications are given by manufacturers will used as listed in Table 1. The following parameters are used in the experiments that taking account in the proposed model.

Table 1. Models' Specification Model

JAM6 72/300/SI

Characteristics

Maximum Power $\left(P_{m p p}\right)$

Maximum Power Voltage $\left(V_{m p}\right)$

Maximum Power Current ( $\left.I_{m p}\right)$

Short-circuit current $\left(I_{s c}\right)$

Open-circuit voltage $\left(V_{o c}\right)$

Temperature coefficient of

short-circuit current $\left(K_{I}\right)$

It shows when the parameter changed then the proposed mathematical modelling still produces the expected result nicely. This is discussed in all the insights generated by Matlab. Besides, the difference of temperature and solar irradiance, this proposed model in good argument.

The goal is to find the value of resistances that influence by environmental factor. Figure 2 shows the calculation of $R_{S}$ and $R_{S H}$ using the proposed mathematical model.

As shown in the figures, the value of $R_{S}$ and $R_{S H}$ are slowly changes with respect to temperature. The value of both resistances increased when the temperature increase.

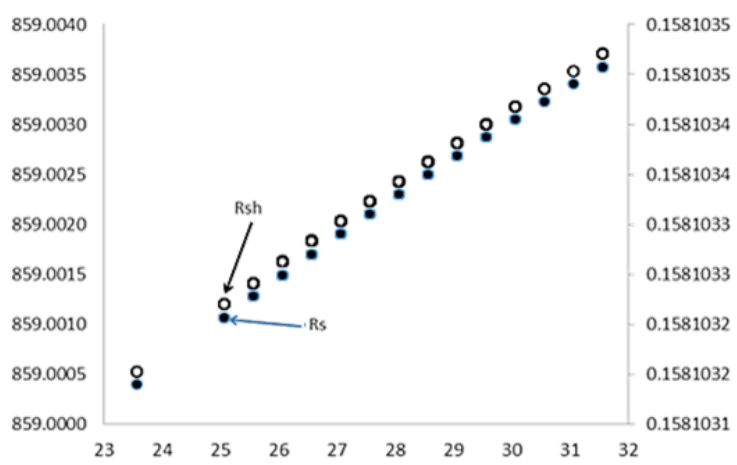

Figure 3. Resistance characteristics with various temperature.

The following Figure 4 shows the plotting of versus temperature. It shows that $a$ is changing influenced by $T$. The value of $a$ decreases as the temperature increases. In our mathematical model, $a$ will affect the calculation for $I$ and $P$. On top of that, $a$ is influenced by $T$. Temperature is the crucial factor in computing the performance of photovoltaic model.

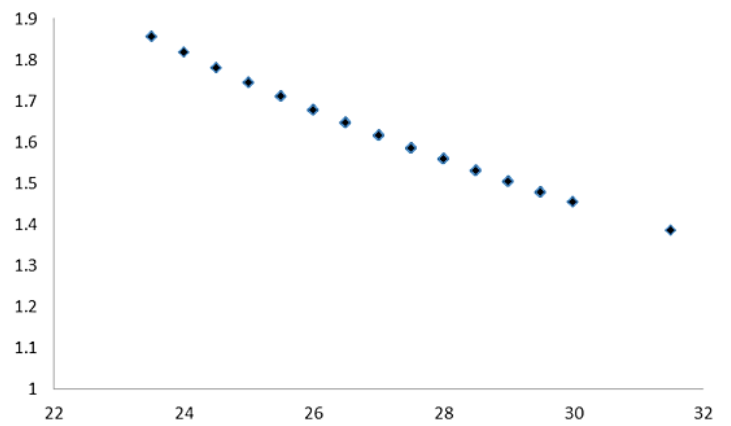

Figure 4 . The ideality diode factors with temperatures. 
Other previous research simply assumed the value of as a constant (Shukla et al., 2016; Mares et al., 2015; Chin et al., 2015) determined the value of a in the range of 1 by using the parameter fitting method. The same value would use in various different model and varying temperature or solar irradiance that used in the modelling (Shukla et al., 2016).

Figure 5 and Figure 6 show the $I-V$ curves and $P$ - $V$ curves respectively using the proposed mathematical model for different hardware photovoltaic models for various temperature level at $T=25,26.5,27.5 \& 29.5$ andvarious solar irradiance level at $G=1000 \mathrm{~W} / \mathrm{m}^{2}, 800 \mathrm{~W} / \mathrm{m}^{2}$ and $600 \mathrm{~W} / \mathrm{m}^{2}$.

It can be seen that different temperature and solar irradiance given different graph. Small different in temperature will give big different in $I$ - $V$ curves and $P$ - $V$ curves. This is due to our mathematical model that compute $R_{S}$ , $R_{S H}$ and $a$ simultaneously. The graph is consistent with the experimental data. This indicates that the actual behaviour of the solar cell can be accurately described by the proposed mathematical modelling.

A decrease in solar irradiance will cause a decrease in efficiency and output power of solar cell (Guo et al., 2016; Chander et al., 2015; Shukla et al., 2015). Solar irradiance increase will directly be affected in producing $I_{P V}$, Equation (5) had calculated and proven the highest $I_{P V}$ most influenced by value of $G$.

In this study, the resistances are reacted with the ambient temperature and influence the $I-V$ and $P-V$ characteristics. An increase in temperature will cause a decrease in efficiency and output power of solar cell (Xu \& Wang (2017), Vergura (2016) and Guo et al., (2016).

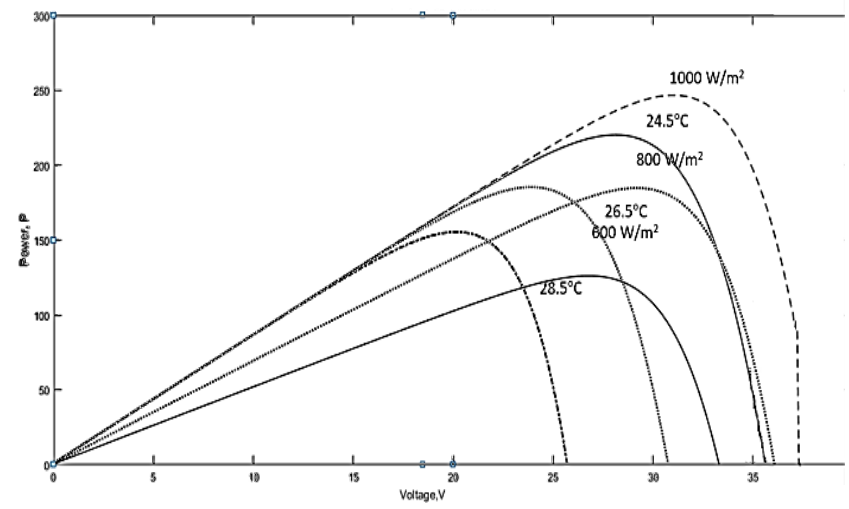

Figure 5. I-V Characteristics with various solar irradiance and temperature.

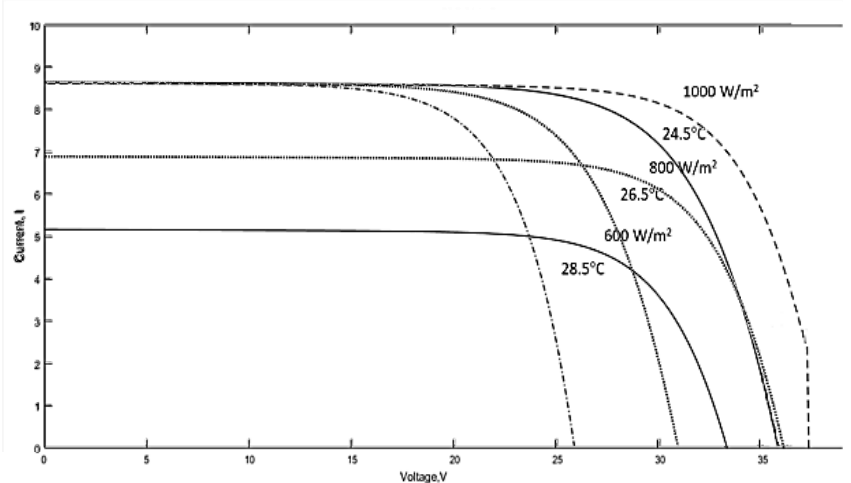

Figure 6. $P-V$ Characteristics with various solar irradiance and temperature.

The results in Figure 5 and Figure 6 are in line with Xu \& Wang (2017); Vergura (2016); Guo et al. (2016). Determination of I and P by computing the model has proven the resistances are strictly increased with respect to solar irradiance and temperature.

\section{CONCLUSION}

The present research aims at improving the mathematical modelling by computing all the values of ideality diode factor, $a$, series resistance, $R_{S}$ and shunt resistance, $R_{S H}$. Most established mathematical models set a certain value for $a$, $R_{S}, R_{S H}$ as the initial data. In order to improve the performance of solar photovoltaic, a model for $a, R_{S}$ and $R_{S H}$ are developed. The values for $a, R_{S}, R_{S H}$ were computed simultaneously using our mathematical formulation that take into account the factor of ambient temperature, $T$. Then, we validated the mathematical model by comparing the calculated data with the experimental data obtained from FKEE, University Malaysia Pahang for each different PV model. Besides, we compared our result with datasheet from the manufacturer. It is found that our mathematical model consistent with the data for any PV model and environmental condition.

\section{ACKNOWLEDGEMENT}

The authors would like to express sincere gratitude to the PGRS180359 for funding this research and to Mohd ShawalJadin from FKEE for providing experimental data support. 


\section{REFERENCES}

Chander, S., Purohit, A., Sharma, A., Arvind, Nehra, S. P., \&

Dhaka, M. S. (2015). A study on photovoltaic parameters of mono-crystalline silicon solar cell with cell temperature. Energy Reports,1,104-109. https: //doi.org/ 10.1016/ j.egyr.2015.03.004

Chin, V. J., Salam, Z., \& Ishaque, K. (2015). Cell modelling and model parameters estimation techniques for photovoltaic simulator application: A review. Applied Energy, 154, 500-519. https://doi.org/10.1016/j.apenergy.2015.05.035

Guo, L., Meng, Z., Sun, Y., \& Wang, L. (2016). Parameter identification and sensitivity analysis of solar cell models with cat swarm optimization algorithm. Energy Conversion and Management, 108,520528.https://doi.org/10.1016/j.enconman.2015.11.041

Hu, Y., \& Yao, Y. (2016). A methodology for calculating photovoltaic field output and effect of solar tracking strategy. Energy Conversion and Management, 126, 278289.https://doi.org/10.1016/j.enconman.2016.08.007

Humada, A. M., Hojabri, M., Mekhilef, S., \& Hamada, H. M. (2016). Solar cell parameters extraction based on single and double-diode models: A review. Renewable and Sustainable Energy Reviews, 56, 494509.https://doi.org/10.1016/j.rser.2015.11.051.

ISE (Fraunhofer Institute for Solar Energy Systems, Institute for Solar). (2016). Photovoltaic Report. Retrieved from www.ise.fraunhofer.

Koohi-Kamali, S., Rahim, N. A., Mokhlis, H., \& Tyagi, V. V. (2016). Photovoltaic electricity generator dynamic modeling methods for smart grid applications: A review. Renewable and Sustainable Energy Reviews, 57, 131172.https://doi.org/10.1016/j.rser.2015.12.137

Mares, O., Paulescu, M., \& Badescu, V. (2015). A simple but accurate procedure for solving the five-parameter model. Energy Conversion and Management, 105, 139-148. https://doi.org/10.1016/j.enconman.2015.07.046

Pachauri, R. K., Allen, M. R., Barros, V. R., Broome, J., Cramer, W., Christ, R., \& Dubash, N. K. (2014). Climate Change 2014. Proceedings of the National Academy of Sciences

(Vol. 108). https://doi.org/10.1073/pnas.1116437108.

Pachauri, R. K., Allen, M. R., Barros, V. R., Broome, J., Cramer, W., Christ, R. \& Dubash, N. K. (2014). Climate change 2014: synthesis report. Contribution of Working Groups I, II and III to the fifth assessment report of the Intergovernmental Panel on Climate Change (p. 151). IPCC.

Rahman, S. A., Vanderheide, T., \& Varma, R. K. (2014). Generalised model of a photovoltaic panel. IET Renewable Power Generation, 8(3), 217-229. https://doi.org/10.1049/iet-rpg.2013.0094

Rosario, A. (2014). Calculating the Solar Energy of a Flat Plate Collector, 6(1), 1-13.

Shukla, A., Khare, M., \& Shukla, K. N. (2015). Modeling and Simulation of Solar PV Module on MATLAB/Simulink. International Journal of Innovative Research in Science, Engineering and Technology (An ISO Certified Organization), $\quad 3297(1), \quad$ 1851618527.https://doi.org/10.15680/IJIRSET.2015.0401015

Suthar, M., Singh, G. K., \& Saini, R. P. (2013). Comparison of mathematical models of photo-voltaic (PV) module and effect of various parameters on its performance. 2013 International Conference on Energy Efficient Technologies for Sustainability, 1354-1359. https://doi.org/10.1109/ICEETS.2013.6533584

Vergura, S. (2016). A complete and simplified datasheetbased model of pv cells in variable environmental conditions for circuit simulation. Energies, 9(5). https://doi.org/10.3390/en9050326

Xu, S., \& Wang, Y. (2017). Parameter estimation of photovoltaic modules using a hybrid flower pollination algorithm. Energy Conversion and Management, 144, 5368.https://doi.org/10.1016/j.enconman.2017.04.042. 